\title{
Revefenacin: First Global Approval
}

\author{
Young-A Heo ${ }^{1}$ \\ Published online: 17 December 2018 \\ (c) Springer Nature 2019, corrected publication 2019
}

\begin{abstract}
Revefenacin (YUPELRI ${ }^{\mathrm{TM}}$ ) inhalation solution, a long-acting muscarinic antagonist (i.e. an anticholinergic) developed by Theravance Biopharma and Mylan, is the first and currently the only once-daily, nebulized bronchodilator to be approved in the USA for the treatment of chronic obstructive pulmonary disease (COPD). In November 2018, based on results of three phase III trials, the US Food and Drug Administration granted market authorization to revefenacin for the maintenance treatment of patients with COPD. This article summarizes the milestones in the development of revefenacin leading to this first global approval.
\end{abstract}

\section{Introduction}

Chronic obstructive pulmonary disease (COPD) is a progressive disease that is characterized by persistent airflow limitation [1]. COPD is associated with considerable medical, social, and economic burden and is expected to be the third leading cause of death worldwide by 2020 . The goal of COPD management is to improve lung function, reduce clinical symptoms of COPD, and prevent future exacerbations. The mainstay maintenance treatment for COPD patients includes inhaled long-acting muscarinic antagonist (LAMAs) and/or long-acting $\beta_{2}$-agonists (LABAs), with or without inhaled corticosteroid (ICS) [1]. Long-acting bronchodilators (e.g. LABAs or LAMAs) are often delivered via hand-held devices, such as a dry powder inhaler (DPI) or a metered dose inhaler (MDI). However, some COPD patients [e.g. the elderly, cognitively impaired or physically limited and with suboptimal peak inspiratory flow rates (PIFR)] find it difficult to use such devices, resulting in inaccurate dosing, poor adherence, and potentially poor clinical outcomes [2]. For these patients, nebulized drug delivery, which is easier to use and provides similar efficacy to hand-held inhalers

This profile has been extracted and modified from the AdisInsight database. AdisInsight tracks drug development worldwide through the entire development process, from discovery, through preclinical and clinical studies to market launch and beyond.

Young-A Heo

dru@adis.com

1 Springer, Private Bag 65901, Mairangi Bay, Auckland 0754, New Zealand can be an alternative treatment option. However, nebulized bronchodilator therapy options for the maintenance treatment of COPD are currently limited [2].

Revefenacin (YUPELRI ${ }^{\mathrm{TM}}$ [3]) inhalation solution is a oncedaily nebulized LAMA that has been developed by Theravance Biopharma and Mylan for the maintenance treatment of patients with COPD [4]. Revefenacin is a potent, lung-selective LAMA that prevents bronchoconstriction by inhibiting muscarinic $\mathrm{M}_{3}$ receptors in airway smooth muscle. Revefenacin received its first global approval on 9 November 2018 in the USA for maintenance treatment of patients with COPD [4]. The approved dosage of revefenacin inhalation solution is $175 \mu \mathrm{g}$ once daily, delivered via a standard jet nebulizer connected to an air compressor [3]. Revefenacin should not be used to relieve acute symptoms of COPD (i.e. as a rescue therapy) and should not be initiated in patients experiencing acutely deteriorating or potentially life-threatening episodes of COPD. Revefenacin should be discontinued immediately if patients develop paradoxical bronchospasm or immediate hypersensitivity reactions [3].

In preliminary development, revefenacin was undergoing clinical investigation in South Africa, New Zealand, Germany and the United Kingdom for the treatment of COPD; however, no recent development reports have been identified outside the USA.

\subsection{Company Agreements and Patent Information}

GlaxoSmithKline (GSK) licensed revefenacin from Theravance in 2004, but the right was returned to Theravance in 


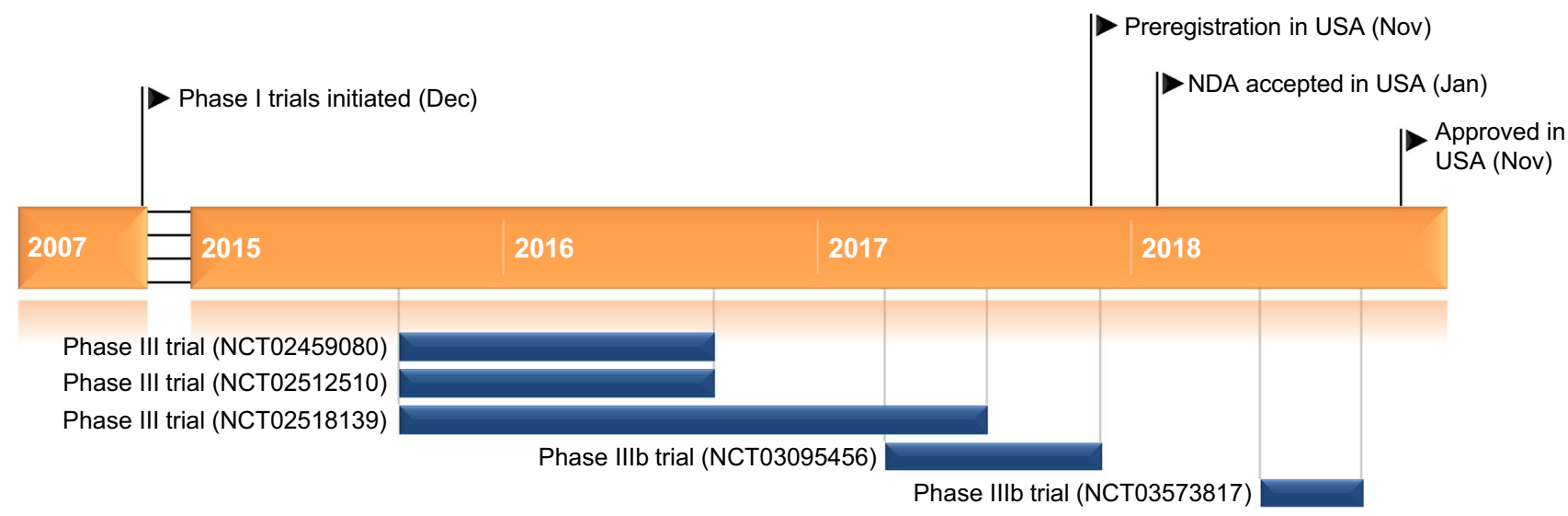

Key milestones in the development of revefenacin for the treatment of chronic obstructive pulmonary disease

February 2009 due to its incompatibility with GSK's proprietary inhaler device [5].

In June 2014, Theravance Biopharma was separated from Theravance (now Innoviva) to focus on the discovery, development and commercialization of small molecule medications across multiple therapeutic areas, including respiratory disease [6].

In January 2015, Theravance Biopharma entered into a collaboration with Mylan, for the development and commercialization of nebulized revefenacin for the treatment of COPD and other respiratory diseases [7]. Under the terms of the agreement, Mylan provides reimbursements for the costs of the US registrational program that is led by Theravance Biopharma; following the approval of the first new drug application in the USA, costs will be shared between the two companies [7]. Mylan has the global right to develop and commercialize nebulized revefenacin (except in China where Theravance Biopharma holds the full rights). Theravance Biopharma retains co-promotion rights in the USA under a profit-sharing arrangement (65\% Mylan and 35\% Theravance Biopharma) [8]. Theravance Biopharma is eligible to receive potential development and sales-based milestone payments (up to $\$ 220$ million) in the USA plus double-digit royalties on net sales on territories outside of the USA. Theravance Biopharma retains the global right to revefenacin delivered through other dosage forms (e.g. MDI or DPI) although Mylan has certain rights of first negotiation with respect to future development and commercialization of revefenacin delivered other than via a nebulized inhalation product [7, 8]. Theravance Biopharma currently has patent protection for the nebulized formulation of revefenacin in the USA until 2025 (not including any patent term extensions that may be available).

\section{Scientific Summary}

\subsection{Pharmacodynamics}

Revefenacin is a potent LAMA that binds competitively and reversibly to the $\mathrm{M}_{3}$ receptors in the airway smooth muscle, thereby inhibiting bronchoconstriction and increasing bronchodilation [9]. In vitro, in Chinese hamster ovary-K1 cell membrane fractions stably expressing human recombinant muscarinic receptors $\mathrm{M}_{1}-\mathrm{M}_{5}$, revefenacin shows similar, high affinity (pKi 8.2-9.8) and displays kinetic functional selectivity (i.e. slower receptor dissociation) for human $\mathrm{M}_{3}$ compared with $\mathrm{M}_{2}$ receptors. The dissociation half-life was significantly $(p<0.05)$ longer for $\mathrm{M}_{3}$ than $\mathrm{M}_{2}$ receptors (82 vs. 6.9 mins) [9]. Following inhalation of revefenacin, bronchodilation is mainly site-specific [3].

In vitro, revefenacin antagonized muscarinic acetylcholine cholinergic receptor-mediated contractions for up to $24 \mathrm{~h}$ in rat and guinea pig tracheal tissues, as well as in human airway muscle tissues [9]. In anesthetized dogs and rats, single or repeated dosing (once daily for 7 days) of inhaled revefenacin provided a dose-dependent bronchoprotection against acetylcholine- or methacholine-induced<smiles>CN(CCN1CCC(OC(=O)Nc2ccccc2-c2ccccc2)CC1)C(=O)c1ccc(CN2CCC(C(N)=O)CC2)cc1</smiles>

Chemical structure of revefenacin 
bronchoconstriction [10]. The bronchoprotective effect was seen as early as 5 min post-dose and was sustained for up to $24 \mathrm{~h}$. In these animal models, repeated once daily dosing of revefenacin also exhibited superior functional lung selectivity index over repeated dosing of tiotropium (i.e. once daily LAMA therapy) and glycopyrronium (i.e. twice daily LAMA therapy). After repeated dosing, the bronchoprotective potency of revefenacin and tiotropium was maintained, unlike glycopyrronium [10].

In a thorough, positive-controlled QT study in healthy subjects $(n=48)$, a therapeutic $(175 \mu \mathrm{g})$ or supratherapeutic $(700 \mu \mathrm{g})$ dose of inhaled revefenacin did not prolong QTc interval to any clinically meaningful extent [11]. In two 12-week phase III efficacy trials and a 52-week safety phase III trial in patients with moderate to very severe COPD (Sect. 2.3), long-term use of inhaled revefenacin (up to 52 weeks) had no clinically relevant effect on QTc interval compared with placebo [11].

\subsection{Pharmacokinetics}

After inhaled administration in COPD patients, revefenacin is rapidly metabolized in the liver to its major active metabolite (THRX-195518), with its plasma exposure [based on area under the plasma concentration-time curve (AUC)] being 4- to 6-fold greater than revefenacin [3, 12]. The potency of the metabolite THRX-195518 at muscarinic receptors is one-third to one-tenth lower relative to revefenacin [3]. Exposures to revefenacin and its active metabolite increased in a slightly greater than dose-proportional manner across a dose range of $88-700 \mu \mathrm{g}$ when administered as a single or multiple inhaled doses [3]. The pharmacokinetic profile of revefenacin was best described with a 2-compartment model with first-order absorption and elimination [13].

In healthy volunteers and in COPD patients, peak plasma concentrations $\left(\mathrm{C}_{\max }\right)$ of revefenacin and its active metabolite occurred 14-41 min after start of nebulization; the absolute bioavailability of revefenacin following oral administration is very low $(<3 \%)$ [3]. Following repeated administration of inhaled revefenacin, steady state was reached within 7 days, with $<1$.6-fold accumulation. In COPD patients, exposure (i.e. $\mathrm{C}_{\max }$ and AUC) to revefenacin was $\approx 60 \%$ lower but exposure to active metabolite was $\approx 2$-fold higher than healthy volunteers [3].

Following intravenous administration of revefenacin in healthy volunteers, the mean steady-state volume of distribution was $218 \mathrm{~L}$ [3]. In vitro human plasma protein binding for revefenacin and its active metabolite averaged 71 and $42 \%$ [3].

After intravenous administration of revefenacin in healthy volunteers, $\approx 54 \%$ of the radioactivity was recovered in faeces $(\approx 19 \%$ as the active metabolite) and $27 \%$ was recovered in urine $[3,14]$. Following oral administration of a single dose of radiolabelled revefenacin, $88 \%$ of the radioactivity was recovered in faeces and $<5 \%$ was recovered in urine, suggesting poor oral absorption. Following inhaled administration in COPD patients, revefenacin and its active metabolite were minimally excreted via the renal route $(<1 \%)[3,14]$. The elimination half-life of revefenacin and its active metabolite after once daily dosing of inhaled revefenacin in COPD patients is $22-70 \mathrm{~h} \mathrm{[3]}$.

A population pharmacokinetic analysis indicated that systemic exposure of revefenacin and its active metabolite are not significantly affected by age, gender, smoking status or weight [3]. Revefenacin is not recommended in patients with any degree of hepatic impairment as the safety of revefenacin has not been studied in COPD patients with mild to severe hepatic impairment [3]. Dosage adjustments are not required in patients with renal impairment. However, $\mathrm{C}_{\max }$ and AUC of revefenacin and its active metabolite increased up to 2.5 -fold in patients with severe renal impairment; thus, monitoring for systemic antimuscarinic adverse events (AEs) is recommended in this population [3].

Coadministration of revefenacin with other anticholinergic medications should be avoided as concomitant use of these drugs may increase the risk of anticholinergic AEs (e.g. acute narrow-angle glaucoma, urinary retention) [3]. Coadministration of revefenacin with OATP1B1 and OATP1B3 inhibitors (e.g. rifampicin, cyclosporine) is also not recommended as it may increase systemic exposure of the active metabolite of revefenacin [3].

\subsection{Therapeutic Trials}

\subsubsection{Phase III Trials}

Twelve weeks of revefenacin treatment effectively improved lung function [as assessed by forced expiratory volume in $\left.1 \mathrm{~s}\left(\mathrm{FEV}_{1}\right)\right]$ in patients aged $>40$ years with moderate to very severe COPD in two replicate, randomized, double-blind, placebo-controlled trials (NCT02459080 and NCT02512510) $[15,16]$. Pooled data showed that, compared with placebo $(n=428)$, patients treated with once daily revefenacin $88 \mu \mathrm{g}(n=425)$ or $175 \mu \mathrm{g}(n=402)$ via a standard jet nebulizer experienced significantly $(p \leq 0.001)$ greater improvements in the $24 \mathrm{~h}$ change from baseline in trough $\mathrm{FEV}_{1}$ on day 85 [between-group differences (BGDs) $118 \mathrm{~mL}$ (95\% CI 86-150 mL) and $145 \mathrm{~mL}$ (95\% CI $113-178 \mathrm{~mL}$ )] (primary endpoint) and the overall treatment effect in trough $\mathrm{FEV}_{1}$ over 12 weeks $(88 \mu \mathrm{g}$ : BGD $112 \mathrm{~mL}, 95 \%$ CI $106-118 \mathrm{~mL} ; 175 \mu \mathrm{g}$ : BGD $139 \mathrm{~mL}, 95 \%$ CI $133-145 \mathrm{~mL})[15,16]$. The treatment benefits of either dosage of revefenacin were consistently seen in subgroup of patients with higher risk of COPD exacerbations, including in the elderly ( $>65$ years), those receiving concomitant therapy (LABA or ICS) and those with very severe COPD 


\begin{tabular}{ll} 
Alternative names & 1160724; GSK 1160724; TD-4028; YUPELRI \\
\hline Class & Antiasthmatics; biphenyl compounds; bronchodilators; carbamates; piperidines \\
$\begin{array}{l}\text { Mechanism of action } \\
\text { Route of administration }\end{array}$ & $\begin{array}{l}\text { Muscarinic receptor antagonist } \\
\text { Inhalation }\end{array}$ \\
$\begin{array}{l}\text { Pharmacodynamics } \\
\text { Inhibits muscarinic receptor } \mathrm{M}_{3} \text { in the airway smooth muscle, leading to bron- } \\
\text { chodilation }\end{array}$ \\
\begin{tabular}{ll} 
Pharmacokinetics (after inhaled administration) & Time to $\mathrm{C}_{\text {max }}$ 14-41 min; elimination half-life $22-70 \mathrm{~h}$ \\
\hline Most frequent adverse events & Cough, headache, upper respiratory tract infection, nasopharyngitis and back pain \\
\hline $\begin{array}{l}\text { ATC codes } \\
\text { WHO ATC code }\end{array}$ & R03B-B (Anticholinergics) \\
\hline EphMRA ATC code & R3G3 (Anticholinergics-plain, inhalant) \\
\hline Chemical name & [1-[2-[[4-[(4-carbamoylpiperidin-1-yl)methyl]benzoyl]-methylamino]ethyl] \\
piperidin-4-yl] N-(2-phenylphenyl)carbamate
\end{tabular} \\
\hline
\end{tabular}

[classified as Global Initiative for COPD category D (GOLD D)] ( $p$ value not reported) [17]. According to a $24 \mathrm{~h}$ serial spirometry substudy $(n=264)$ on day 84 , revefenacin 88 or $175 \mu \mathrm{g}$ were associated with significant $(p<0.01)$ improvements in trough $\mathrm{FEV}_{1}$ at all time points compared with placebo (BGDs 111-185 and 154-269 mL) [18], indicating bronchodilation was sustained for at least $24 \mathrm{~h}$ post-dose. Both dosages of revefenacin were associated with a nominal reduction in the annualized rate of COPD exacerbations but the differences compared with the placebo group were not statistically significant [19].

Significant $(p \leq 0.0203)$ improvements from baseline in health-related quality of life indicators [assessed by St. George's Respiratory Questionnaire (SGRQ) and COPD Assessment Test (CAT)] with either revefenacin dosage versus placebo were only shown in one (NCT02459080) of the two replicate trials. Despite improvements from baseline in the revefenacin $175 \mu \mathrm{g}$ group, a greater than expected response in the placebo group prevented statistically significant differences in the second trial (NCT02512510) [20]. At entry, patients in the two replicate trials had a mean age of 63.7 years, a mean smoking history of 52.3 pack-years (49\% of patients were current smokers [16]) and the mean predicted $\mathrm{FEV}_{1}$ was $54.4 \%$; $38.1 \%$ of patients were taking concomitant LABA or LABA/ICS therapy and $34.5 \%$ had very severe COPD (classified as GOLD D) [15]. These trials included patients with moderate to very severe COPD (post-ipratropium $\mathrm{FEV}_{1} \leq 80 \%$ of predicted and $\geq 700 \mathrm{~mL}$ ), a smoking history of $\geq 10$ pack-years and a $\mathrm{FEV}_{1} /$ forced vital capacity $(\mathrm{FVC})$ ratio of $<0.7$ [3]. Patients with narrow-angle glaucoma, unstable cardiac disease or symptomatic prostatic hypertrophy or bladder outlet obstruction were excluded [3].

In a randomized, double-blind phase IIIb study (NCT03095456), 207 patients with moderate to very severe COPD and suboptimal PIFR ( $<60 \mathrm{~L} / \mathrm{min}$ ) were randomized to receive revefenacin $175 \mu \mathrm{g}$ once daily via a standard jet nebulizer or tiotropium once daily via HandiHaler ${ }^{\circledR}$ for 28 days [17, 21]. On day 29, revefenacin and tiotropium effectively improved trough $\mathrm{FEV}_{1}$ and FVC from baseline, with improvements numerically favouring revefenacin over tiotropium; however, these differences did not reach statistical significance $\left(\mathrm{FEV}_{1}: p=0.481\right.$; FVC: $\left.p=0.104\right)$. In a prespecified subgroup analysis, revefenacin significantly ( $p \leq 0.0407$ ) improved trough $\mathrm{FEV}_{1}$ and $\mathrm{FVC}$ from baseline compared with tiotropium in patients with severe to very severe COPD (i.e. $\mathrm{FEV}_{1}<50 \%$ of predicted), which accounted for $\approx 80 \%$ of enrolled patients $[17,21]$.

In efficacy analyses from a 52-week, randomized, partially blind, active-controlled safety phase III study (NCT02518139; $n=1055$ [17, 22]), relative to placebo, inhaled revefenacin 88 or $175 \mu \mathrm{g}$ once daily provided longterm improvement in trough $\mathrm{FEV}_{1}$ from baseline in the subgroups of patients with moderate to very severe COPD who received concomitant LABA or ICS therapy or those aged 65 years ( $p$ value not reported) [17]. The study also included open-label tiotropium (active control) and assessed the impact of revefenacin and tiotropium on the annualized rate of COPD exacerbations; there were no significant differences across treatment groups [19]. At entry, patients had a mean age of 64 years and a mean predicted $\mathrm{FEV}_{1}$ of $54 \%$; $46 \%$ of patients were current smokers and $50 \%$ were taking concomitant LABA $(2.2 \%)$ or LABA/ICS (47.8\%) therapy [23].

\subsubsection{Phase II trials}

Compared with placebo, in a randomized, double-blind, placebo-controlled, dose-ranging phase II study in patients with moderate to severe COPD (NCT02040792; $n=355$ ), least squares mean (LSM) trough $\mathrm{FEV}_{1}$ from baseline on day 28 significantly improved in the revefenacin 88,175 and $350 \mu \mathrm{g}$ once daily groups (134.2-155.0 vs. $-32.4 \mathrm{~mL}$; 
all $p<0.001$ ), but not with revefenacin $44 \mu \mathrm{g}$ once daily [2]. At $4 \mathrm{~h}$ post-dose, $\geq 100 \mathrm{~mL}$ increase in $\mathrm{FEV}_{1}$ from baseline was evident in $>80 \%$ of patients receiving a revefenacin dosage $\geq 88 \mu \mathrm{g} /$ day. Inhaled revefenacin dosages $\geq 88 \mu \mathrm{g} /$ day also significantly $(p<0.005)$ decreased the use of rescue medication (i.e. albuterol) compared with placebo. Revefenacin $350 \mu \mathrm{g} / \mathrm{day}$ did not show additional efficacy benefit over revefenacin $175 \mu \mathrm{g} /$ day [2].

NCT02040792 enrolled patients (aged 40-75 years) with moderate to severe COPD (pre-bronchodilator FEV 1 $30-80 \%$ of predicted and post-ipratropium $\mathrm{FEV}_{1} / \mathrm{FVC}$ ratio of $<0.7$ ) and a smoking history of $>10$ pack-years [2]. At entry, patients had a mean age of 61.9 years, a mean smoking history of 39.5 pack-years $(53.7 \%$ of patients were current smokers) and a mean predicted $\mathrm{FEV}_{1}$ of $43.6 \% ; 36.7 \%$ of patients were currently using ICS. Patients were randomized to receive inhaled revefenacin $44,88,175$ or $350 \mu \mathrm{g}$ once daily or placebo for 28 days [2].

Inhaled revefenacin $22-700 \mu \mathrm{g}$ once daily via a standard jet nebulizer provided rapid and sustained bronchodilation in patients with moderate to severe COPD in two randomized, double-blind, placebo-controlled, dose-finding phase II studies (NCT03064113 and NCT01704404) [12]. In NCT03604113 $(n=32)$, a significant $(p<0.001)$ increase from baseline in the LSM peak $(0-6 \mathrm{~h}) \mathrm{FEV}_{1}$ was observed with single dose inhaled revefenacin (350 or $700 \mu \mathrm{g}$ ) or ipratropium $500 \mu \mathrm{g}$ (active control) compared with placebo (1838.9-1867.3 vs. $1676.7 \mathrm{~mL}$ ). The onset and the magnitude of the bronchodilator effect with revefenacin was similar to that seen with ipratropium. In NCT01704404 $(n=59)$, a 7-day treatment course of revefenacin $(22,44,88,175,350$ or $700 \mu$ g once daily) significantly $(p \leq 0.006)$ increased LSM trough $\mathrm{FEV}_{1}$ from baseline on day 7 compared with placebo (91.2-151.9 vs. $37.8 \mathrm{~mL}$ ). In both studies, the bronchodilator effect of revefenacin was maintained for at least $24 \mathrm{~h}$ post-dose. In addition, a minimal clinically important difference for $\mathrm{FEV}_{1}$ was achieved in patients receiving revefenacin doses $\geq 88 \mu \mathrm{g}$ and the dose response appeared to plateau at doses $\geq 175 \mu \mathrm{g}$ [12].

NCT03064113 and NCT01704404 enrolled patients (aged 40-75 years) with moderate to severe COPD (prebronchodilator $\mathrm{FEV}_{1} 35-80 \%$ of predicted and $\mathrm{FEV}_{1} / \mathrm{FVC}$ ratio of $<0.7$ ) and a smoking history of $>10$ pack-years [12]. At entry, patients in these trials had a mean age of 62.0 and 63.9 years and a mean predicted $\mathrm{FEV}_{1}$ of 50.5 and $47.2 \%$. NCT03064113 was conducted in South Africa and New Zealand and NCT01704404 was conducted in United Kingdom, Northern Ireland and New Zealand [12].

\begin{tabular}{|c|c|c|c|c|c|}
\hline $\operatorname{Drug}(s)$ & Indication & Phase & Status & Location(s) & Identifier \\
\hline Revefenacin, placebo & $\begin{array}{l}\text { Adults (aged }>40 \text { years) with } \\
\text { moderate to very severe COPD }\end{array}$ & III & Completed & USA & NCT02459080 \\
\hline Revefenacin, placebo & $\begin{array}{l}\text { Adults (aged }>40 \text { years) with } \\
\text { moderate to very severe COPD }\end{array}$ & III & Completed & USA & NCT02512510 \\
\hline Revefenacin, tiotropium & $\begin{array}{l}\text { Adults (aged }>40 \text { years) with } \\
\text { moderate to very severe COPD }\end{array}$ & III & Completed & USA & NCT02518139 \\
\hline Revefenacin, tiotropium & $\begin{array}{l}\text { Adults (aged }>40 \text { years) with } \\
\text { moderate to very severe COPD } \\
\text { and a low PIFR }(<60 \mathrm{~L} / \mathrm{min})\end{array}$ & IIIb & Completed & USA & NCT03095456 \\
\hline $\begin{array}{l}\text { Revefenacin, formoterol, } \\
\text { placebo }\end{array}$ & $\begin{array}{l}\text { Adults (aged }>40 \text { years) with } \\
\text { moderate to very severe COPD }\end{array}$ & IIIb & Completed & USA & NCT03573817 \\
\hline Revefenacin, placebo & $\begin{array}{l}\text { Adults (aged } 40-75 \text { years) with } \\
\text { moderate to severe COPD }\end{array}$ & II & Completed & USA & NCT02040792 \\
\hline $\begin{array}{l}\text { Revefenacin, ipratropium, } \\
\text { placebo }\end{array}$ & $\begin{array}{l}\text { Adults (aged } 40-75 \text { years) with } \\
\text { moderate to severe COPD }\end{array}$ & II & Completed & $\begin{array}{l}\text { New Zealand, South } \\
\text { Africa }\end{array}$ & $\begin{array}{l}\text { NCT03064113; ANZCTR } \\
\text { U1111-1120-8290 }\end{array}$ \\
\hline Revefenacin, placebo & $\begin{array}{l}\text { Adults (aged } 40-75 \text { years) with } \\
\text { moderate to severe COPD }\end{array}$ & II & Completed & $\begin{array}{l}\text { United Kingdom, } \\
\text { Northern Ireland and } \\
\text { New Zealand }\end{array}$ & NCT01704404 \\
\hline
\end{tabular}

$C O P D$ chronic obstructive pulmonary disease, $P I F R$ peak inspiratory flow rate 


\subsection{Adverse Events}

Revefenacin inhalation solution was generally well tolerated in patients with moderate to very severe COPD in clinical trials [3]. In a pooled analysis of NCT02459080 and NCT02512510, at least one any-grade AE was reported in $53.4,50.7$ and $48.3 \%$ of patients receiving revefenacin 88 or $175 \mu \mathrm{g}$ or placebo once daily, respectively [24]. The most common AEs occurring in $\geq 2 \%$ of patients with a higher incidence in revefenacin 88 or $175 \mu \mathrm{g}$ than placebo recipients were cough ( 4.0 and 4.2 vs. $4.0 \%$ ), headache (4.9 and 4.0 vs. $2.6 \%$ ), upper respiratory tract infection (4.7 and 2.7 vs. $2.1 \%$ ), nasopharyngitis (3.3 and 3.7 vs. $2.1 \%$ ) and back pain (1.4 and 2.2 vs. $0.7 \%$ ). The incidence of antimuscarinic AEs and serious AEs were low and similar across treatment groups [24, 25]. Where reported, AEs leading to treatment discontinuation occurred in $13 \%$ of revefenacin $175 \mu \mathrm{g}$ recipients and $19 \%$ of placebo recipients [3].

The tolerability profile of revefenacin in patients with moderate to very severe COPD in the 52-week safety phase III study (NCT02518139; Sect. 2.3) was generally similar to that observed in the two 12-week studies and revealed no new safety signals [3]. The frequency and severity of treatment-emergent AEs, as well as instances of major adverse cardiovascular events were generally similar across treatment groups [23].

\subsection{Ongoing Trials}

Currently, there are no ongoing trials identified for revefenacin inhalation solution.

\section{Current Status}

Revefenacin inhalation solution received its first global approval on 9 November 2018 in the USA for the maintenance treatment of patients with COPD.

\section{Compliance with Ethical Standards}

Funding The preparation of this review was not supported by any external funding.

Conflict of interest During the peer review process the manufacturer of the agent under review was offered an opportunity to comment on the article. Changes resulting from any comments received were made by the author on the basis of scientific completeness and accuracy. Young-A Heo is a salaried employee of Adis/Springer, is responsible for the article content and declares no relevant conflicts of interest
Open Access This article is distributed under the terms of the Creative Commons Attribution-NonCommercial 4.0 International License (http://creativecommons.org/licenses/by-nc/4.0/), which permits any noncommercial use, duplication, adaptation, distribution and reproduction in any medium or format, as long as you give appropriate credit to the original author(s) and the source, provide a link to the Creative Commons license and indicate if changes were made.

\section{References}

1. Global Initiative for Chronic Obstructive Lung Disease (GOLD). Global strategy for the diagnosis, management, and prevention of chronic obstructive pulmonary disease. 2018. http://goldcopd. org/. Accessed 20 Nov 2018.

2. Pudi KK, Barnes CN, Moran EJ, et al. A 28-day, randomized, double-blind, placebo-controlled, parallel group study of nebulized revefenacin in patients with chronic obstructive pulmonary disease. Respir Res. 2017;18(1):182.

3. Mylan. YUPELRI ${ }^{\mathrm{TM}}$ (revefenacin): US prescribing information. 2018. http://www.fda.gov. Accessed 13 Nov 2018.

4. Theravance Biopharma. Theravance Biopharma and Mylan receive FDA approval for YUPELRI ${ }^{\mathrm{TM}}$ (revefenacin) in adults with chronic obstructive pulmonary disease [media release]. 9 Nov 2018.

5. Theravance. Theravance announces clinical results in the LAMA respiratory program for the treatment of COPD [media release]. 14 July 2008.

6. Theravance. Theravance, Inc. and Theravance Biopharma, Inc. announce completion of separation of late-stage partnered respiratory assets from Biopharmaceutical operations [media release]. 2 June 2014

7. Theravance Biopharma, Mylan. Theravance Biopharma and Mylan partner to develop and commercialize a novel LAMA compound, TD-4208, for COPD [media release]. 2 Feb 2015.

8. Theravance Biopharma. Theravance Biopharma and Mylan initiate phase 3 program for revefenacin (TD-4208) for treatment of chronic obstructive pulmonary disease (COPD) [media release]. 14 Sept 2015.

9. Hegde SS, Pulido-Rios MT, Luttmann MA, et al. Pharmacological properties of revefenacin (TD-4208), a novel, nebulized longacting, and lung selective muscarinic antagonist, at human recombinant muscarinic receptors and in rat, guinea pig, and human isolated airway tissues. Pharmacol Res Perspect. 2018. https:// doi.org/10.1002/prp2.400.

10. Pulido-Rios MT, McNamara A, Obedencio GP, et al. In vivo pharmacological characterization of TD-4208, a novel lung-selective inhaled muscarinic antagonist with sustained bronchoprotective effect in experimental animal models. J Pharmacol Exp Ther. 2013;346(2):241-50.

11. Donohue J, Feldman G, Sethi S, et al. Cardiovascular safety of revefenacin for nebulization: a review of randomized controlled trial data [abstract]. Chest. 2018;154(4 Suppl):734A-5A.

12. Quinn D, Barnes CN, Yates W, et al. Pharmacodynamics, pharmacokinetics and safety of revefenacin (TD-4208), a long-acting muscarinic antagonist, in patients with chronic obstructive pulmonary disease (COPD): results of two randomized, double-blind, phase 2 studies. Pulm Pharmacol Ther. 2018;48:71-9.

13. Lo A, Borin MT, Bourdet DL. Sequential modeling of the population pharmacokinetics of revefenacin and its major metabolite in COPD patients [abstract no. M-015]. J Pharmacokinet Pharmacodyn. 2018;45(Suppl 1):S9. 
14. Bourdet D, Yeola S, Colson P, et al. Absorption, distribution, metabolism, and excretion of revefenacin, a long-acting muscarinic antagonist (LAMA), in healthy male subjects [abstract no. A3033]. Am J Respir Crit Care Med. 2018;197:A3033.

15. Theravance Biopharma. Revefenacin (TD-4208) phase 3 efficacy results. [media release]. 13 Nov 2016.

16. Ferguson GT, Pudi KK, Pendyala S, et al. Efficacy of revefenacin, a novel once-daily nebulized long-acting muscarinic antagonist: Results of two randomized, double-blind, placebo-controlled, parallel-group phase 3 trials in participants with moderate to very severe chronic obstructive pulmonary disease [abstract no. A5474]. Am J Respir Crit Care Med. 2017;195:A5474.

17. Theravance Biopharma, Mylan. Theravance Biopharma and Mylan report positive new data from multiple studies of YUPELRI(T) (revefenacin) at the 2018 CHEST annual meeting [media release]. 11 Oct 2018.

18. Donohue J, Pendyala S, Barnes C, et al. The 24-hour profile of $\mathrm{FEV}_{1}$ after 12-weeks treatment with revefenacin, a once daily long-acting muscarinic receptor antagonists for nebulization: a spirometry substudy [abstract]. Chest. 2017;152(4 Suppl):A770.

19. Donohue J. COPD exacerbations in the phase 3 revefenacin clinical trial program [abstract]. In: 28th Annual Congress of the European Respiratory Society. 2018.

20. Donohue J, Pendyala S, Barnes C, et al. Improvements in health status with revefenacin, a once-daily long-acting muscarinic antagonist for nebulization: changes in St George's respiratory questionnaire and COPD assessment test in replicate 3-month studies [abstract]. Chest. 2017;152(4 Suppl):A819.
21. Mahler D, Ohar J, Barnes C, et al. Efficacy of revefenacin by nebulization and tiotropium by HandiHaler ${ }^{\circledR}$ in subjects with COPD and suboptimal peak inspiratory flow rates (PIFR) [abstract]. Chest. 2018;154(4):732A-3A.

22. Theravance Biopharma, Mylan. Theravance Biopharma and Mylan report new data from phase 3 studies of YUPELRI $\left({ }^{\mathrm{Tm}}\right)$ (revefenacin) in oral presentation at the European Respiratory Society International Congress [media release]. 17 Sept 2018.

23. Kerwin EM, Donohue JF, Sethi S, et al. Revefenacin, a oncedaily, long-acting muscarinic antagonist for nebulized therapy of chronic obstructive pulmonary disease (COPD): results of a 52-week safety and tolerability phase 3 trial in participants with moderate to very severe COPD [abstract no. A4239]. Am J Respir Crit Care Med. 2018;197:A4239.

24. Feldman G, Barnes CN, Moran EJ, et al. Safety and tolerability of revefenacin, a novel once-daily nebulized long-acting muscarinic antagonist: results of two 12-week, randomized, double-blind, placebo-controlled, parallel-group phase 3 trials in participants with moderate to very severe chronic obstructive pulmonary disease [abstract no. A3598]. Am J Respir Crit Care Med. 2017;195:A3598.

25. Theravance Biopharma. Theravance Biopharma and Mylan report additional phase 3 data for revefenacin (TD-4208) in several presentations at 2017 ATS [media release]. 23 May 2017. 